\title{
Active ex situ protection and reestablishment of Dianthus gratianopolitanus Vill. in the "Goździk siny w Grzybnie" reserve (Wielkopolska Province)
}

\author{
Jolanta Jańczyk-Węglarska ${ }^{1}$, Karol Węglarski ${ }^{*}$ \\ \& Justyna Wiland-Szymańska ${ }^{1,2}$
}

\begin{abstract}
'Botanical Garden, Adam Mickiewicz University, Dąbrowskiego 165, 60-594 Poznań, Poland
${ }^{2}$ Department of Plant Taxonomy, Faculty of Biology, Adam Mickiewicz University, Umultowska 89, 61-614 Poznań, Poland

* corresponding author (e-mail: karolw@amu.edu.pl)
\end{abstract}

\begin{abstract}
The following paper presents the results of observations of the size and condition of cheddar pink (Dianthus gratianopolitanus Vill.) population in the "Goździk siny w Grzybnie" reserve (Wielkopolska Province), as well as active cultivation of the species in ex situ controlled conditions and its reestablishment supporting the natural, endangered population in the reserve.
\end{abstract}

Key words: Dianthus gratianopolitanus, ex situ conservation, reestablishment

\section{Introduction}

More and more species are threatened with extinction due to radical changes in vegetation under various human activities (Kornaś 1976; Piękoś-Mirkowa 1990; Kojs 2013). Key elements of protection of plants threatened with extinction, except in situ protection of species by law, are monitoring and active ex situ conservation of their most endangered populations. In Poland, Dianthus gratianopolitanus Vill. is a vulnerable species (VU), strictly protected by law, although in some parts of the country it has a different threat status (Olaczek 2011). This species has been added to the group of critically endangered plants in the Wielkopolska region (CR) (Jackowiak et al. 2007).

Dianthus gratianopolitanus belongs to the suboceanic element of the Europeantemperate zone (Meusel \& Mühlberg 1971-1978; Rothmaler et al. 2005). Its compact range comprises western and northern parts of the Alps. Apart from this location, it has scattered localities occurring from west France and southern part of Belgium, through Germany and Czech Republic, up to southern Poland and western Ukraine (Meusel et al. 1965). Through Poland leads the northern border of its distribution area.
In Poland, Dianthus gratianopolitanus has been reported till now from few, scattered locations with relatively small populations, mostly from the Lower and Upper Silesia, Wielkopolska Province and Małopolska Upland). Altogether, 36 localities of this species are currently known, from which only 14 are treated as confirmed: Lubuskie Province - 3 (Czwałga \& Wasielewski 2002; Sajkiewicz 2003, 2005); Wielkopolska Province - 1 (Węglarski \& Jańczyk-Węglarska 2000); Mazovia Province - 1 (Ferchmin \& Torzewski 2011); Łódź Province - 5 (Olaczek 2011); Opole Province - 2 (Nowak \& Spałek 2002; Kozak et al. 2005); Silesia Province - 1 (Hereźniak 2002); Świętokrzyskie Province - 1 (Łazarski 2011).

Cheddar pink belongs to characteristic xerothermic species preferring calcareous and rocky grasslands of the alliance Seslerio-Festucion duriusculae Klika (1931) 1948 (Rothmaler et al. 2005; Matuszkiewicz 2001). Habitat conditions conducive to the cheddar pink appearance can also be found in very well-lit coniferous forests, belonging to the alliance Dicrano-Pinion Libb. 1933 (Zarzycki 1984; Zarzycki et al. 2002; Czwałga \& Wasielewski 2002; Sajkiewicz 2003). It grows also in gaps among old pine woods, on acid soil, in oak forests classified as Calamagrostio arundinaceae-Quercetum 
petraeae (Hartm. 1934) Scam. et Pass. 1959 community. In spite of the fact that some attempts were made to divide Dianthus gratianopolitanus into varieties in other geographic areas (Kovanda 1982), they were intentionally not used in this work. A separate taxonomic paper concerning this species diversity in Poland is in preparation.

Our work was based on the assumption that cultivation in controlled ex situ conditions and reestablishment of the most endangered populations can be an effective method of rare and endangered species protection.

The aims of this study were to support the endangered natural population of Dianthus gratianopolitanus with specimens originating from the preservative cultivation in the Adam Mickiewicz Botanical Garden in Poznań from seeds collected in the "Goździk siny w Grzybnie" reserve and to develop methodology of the ex situ cultivation of this species.

\section{Material and methods}

The in situ and ex situ research of Dianthus gratianopolitanus was carried out in 1999-2012. The structure of population and also the estimation of the degree and form of the endangerment have been measured. The plants grown in the Adam Mickiewicz Botanical Garden in Poznań from the seeds collected in the reserve (Węglarski \& Jańczyk-Węglarska 2000) were used for vegetative reproduction and, next, for reestablishment and preservation of the species gene pool in the controlled ex situ conditions. The method of spring planting of two-years-old rosettes developed from new annual growth of rhizomes was used.

The species reestablishment was carried out in 2004 based on the protection plan (Borysiak et al. 2003), prepared at the request of the Governor of Wielkopolska Province. The location was formerly prepared by the forest service officers of the Konstantynowo Forest District. Black cherry (Padus serotina Ehrh.) underbrush was removed from this area and a barrier to protect natural population of Dianthus gratianopolitanus was made from pine logs and saplings of Betula pendula Roth. In the present study, some materials were used from the MA Thesis by Zaran-Jaszczak (1995), conducted under the supervision of the authors.

\section{Results and discussion}

\subsection{Morphology of development}

Cheddar pink is a perennial plant, producing loose, blue-green turf with clearly separated concentrations of shoots. They are built out of multi-node vegetative rosettes and leafy, half-rosette generative shoots with 2-3 leaf nodes on flowering stems. New shoots grow out of adventitious buds, located in the leaf axils of vegetative rosettes or at the bases of half-rosette shoots - from their leafless, nearest to the soil, above-ground nodes. Underground nodes of these shoots produce few adventitious roots.

String-like, multi-axially branched underground rhizome and a quite complex primary root system reaching up to $50 \mathrm{~cm}$ are the permanent parts of a plant. New rhizome branches together with the aboveground wintering vegetative rosettes grow in late Summer/ beginning of Autumn from underground adventitious buds situated on 3-5 years old parts of rhizomes. Out of their nodes, a relatively strong system of adventitious roots develops. Annual rhizome growth dies after ca. 7-8 years, which contributes to the disintegration of a polycormic form into offspring plants.

\subsection{Condition of natural population in 1960-2012}

For many years, the studied population was characterized by small but stable numbers of individuals. In 1960 , the population consisted of about 20 polycormic specimens of various size (Wolska 1960).

In 1995, 29 polycormic specimens in 3 locations separated from each other by ca. $10-15 \mathrm{~m}$ were found in the reserve. Their diameter ranged from 50 to $200 \mathrm{~cm}$. However, large clusters with a diameter of $100-160 \mathrm{~cm}$ prevailed.

In 1999, the population size did not change. In 3 sites, 29 specimens in clusters of up to $200 \mathrm{~cm}$ in diameter, covering altogether $23 \mathrm{~m}^{2}$, were noticed. The share of generative shoots ranged from 15 to $32 \%$. Outside the premises of the reserve, the presence of 8 polycormic specimens covering in total $1.25 \mathrm{~m}^{2}(20$ to $60 \mathrm{~cm}$ in diameter) were noted. Vegetative shoots prevailed, amounting to $70-85 \%$ of the total shoot number.

In the recent years, the population size has drastically decreased. In November 2003, the presence of only 5 weak specimens in the reserve was confirmed. They grew only in one place located on the upper part of a hill.

In 2011, 3 small and evidently weak polycormic specimens were recorded. The maximal diameter of clusters ranged from 40 to $60 \mathrm{~cm}$, while the total area covered was only $0.7 \mathrm{~m}^{2}$. The number of shoots amounted to 298 , from which only 53 were generative shoots (21,1\% of all shoots). Outside the reserve, Dianthus gratianopolitanus has not been found.

\subsection{Population reestablished in 2004-2011}

In 2004, in the course of reestablishment process in the reserve, 52 cheddar pink clumps (all blooming specimens), were planted on the total area of $25 \mathrm{~m}^{2}$ with spacing of $0.5 \mathrm{~m}$, on a slope with SE exposure, ca. $15 \mathrm{~m}$ from the existing natural population. In 2011, 40 profusely flowering specimens were noted in the area of reestablishment. Altogether, 2284 shoots were counted 


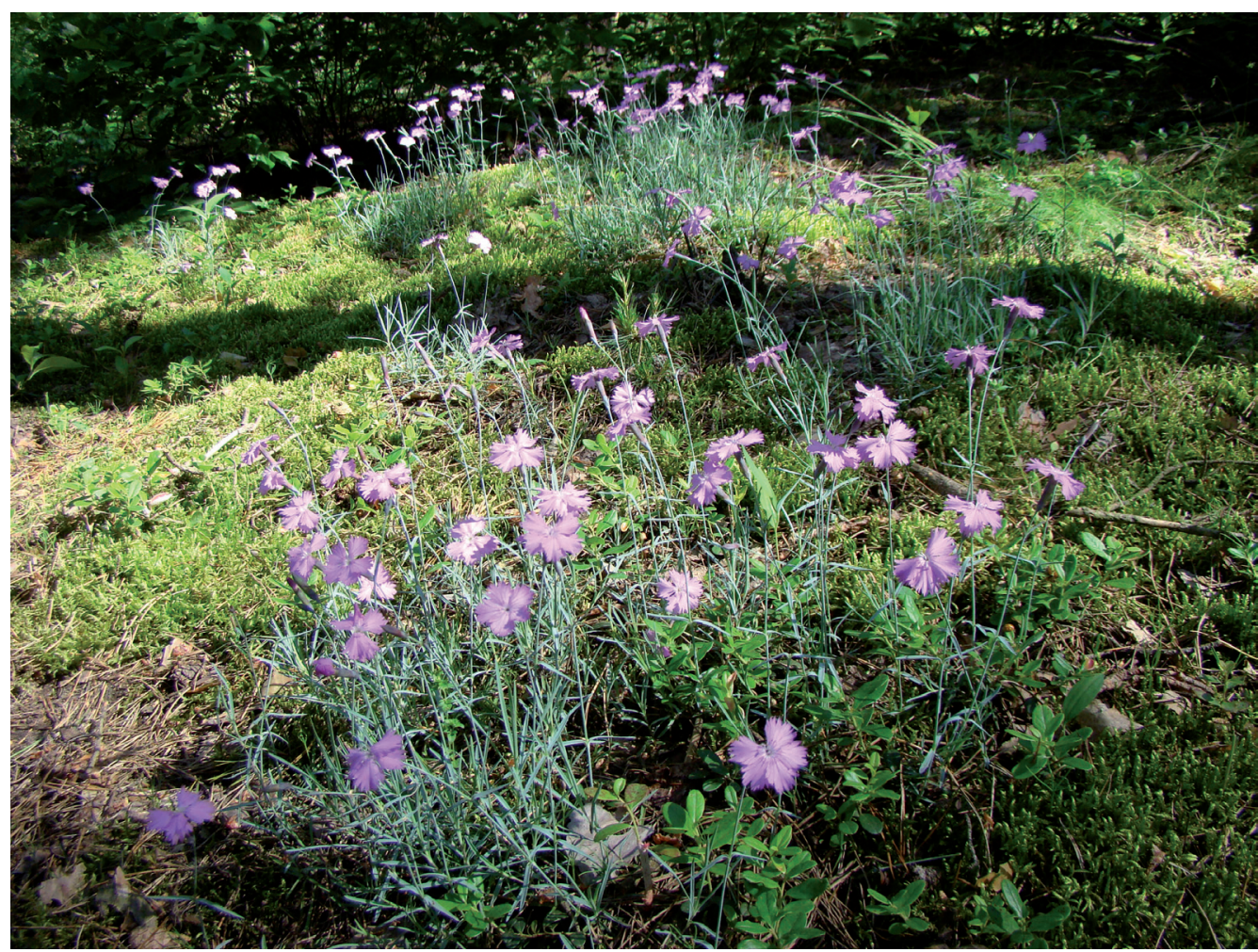

Fig. 1. Condition of the reestablished population of cheddar pink (photograph by K. Węglarski, June 2011)

in the above area - 1480 vegetative and 804 (35,3\% of all shoots) generative ones.

\section{Conclusions}

Reestablishment of natural population of Dianthus gratianopolitanus in the reserve area provided good results - the transplanted specimens remain alive, show compact growth and good lifespan, and do not show any symptoms of diseases (Fig. 1).

Excessive shade resulting from the development of shrubs and large herbaceous plants, especially an invasive spread of Padus serotina and Calamagrostis epigejos (L.) Roth (Węglarski \& Jańczyk-Węglarska 2000), can pose a threat to cheddar pink. In recent years, dead trees and gaps in monoculture pine forests have been observed. At present, black cherry is being removed from the whole reserve. Wild boars can also pose a threat to the population. The damage has already occurred, when they foraged for food in the part of reestablishment area.

Active protection can be one of the effective methods of rescuing this endangered species in in situ conditions. However, existing sites of cheddar pink should be further monitored in order to counteract unfavourable changes to the habitat in time. For the most endangered populations, the maintenance of preservative cultivation in controlled ex situ conditions is necessary. The seeds ought to be secured in a seed bank. In case of special care species, reestablishment and metaplantation of the endangered populations are the effective ways of environmental compensation, but it needs to be mentioned, that clearly defined procedures are lacking (Żółkoś et al. 2010).

\section{References}

Borysiak J., JaŃczyK-Węglarska J. \& WęgLarski K. 2003 (mscr.). Dianthus gratianopolitanus Vill. w rezerwacie "Goździk siny w Grzybnie" (woj. wielkopolskie). Projekt restytucji populacji według wytycznych Komisji Przetrwania Gatunków Światowej Unii Ochrony Przy- rody (IUCN). Projekt Regionalnego Zarządu Lasów Państwowych w Poznaniu.

Czwalga T. \& Wasielewski H. 2002. Rzadkie gatunki roślin w Gryżyńskim Parku Krajobrazowym. Przegląd Przyrodniczy $13(1-2)$ : 25-30. 
Ferchmin M. \& ToRZewsKi K. 2011 (mscr.). Karta monitoringu gatunku - Dianthus gratianopolitanus Vill. 3 pp. Kampinoski Park Narodowy.

HereźNIAK J. 2002. Regionalna lista wymarłych i zagrożonych gatunków roślin naczyniowych północnej części Wyżyny Śląsko-Krakowskiej. Acta Univ. Lodz., Folia Biol. et Oecol. 1: 39-63.

Jackowiak B., Celka Z., Chmiel J., Latowski K. \& Żukowski W. 2007. Red list of vascular flora of Wielkopolska (Poland). Biodiv. Res. Conserv. 5-8: 95-127.

Koss P. 2013. A role of the network of Polish Botanical Gardens in ex situ conservation. International Conference "Ex situ conservation of plants - problems and solutions", Poznań, 23-25 January 2013. Abstracts, p. 12.

KornAś J. 1976. Wymieranie flory europejskiej - fakty, interpretacje, prognozy. Phytocoenosis 5(3-4): 173-185.

Kovanda M. 1982. Dianthus gratianopolitanus: variability, differentiation and relationships. Preslia 54: 223-242.

Kozak M., Nowak A. \& OlszanowsKa-KuńKA K. 2005. Materials to the distribution of threatened vascular plants in the Opole Silesia. Opole Scientific Society Nature Journal 38: 25-55.

ŁAZARSKI G. 2011. Rzadkie i zagrożone gatunki roślin naczyniowych w dolinie Białej Nidy w pobliżu Małogoszcza (centralna część Wyżyny Małopolskiej). Fragm. Flor. Geobot. Polonica 18(2): 257-264.

Matuszkiewicz W. 2001. Przewodnik do oznaczania zbiorowisk roślinnych Polski. In: J. B. FALIŃSKi (ed.). Vademecum Geobotanicum 3, 537 pp. Wyd. Nauk. PWN, Warszawa.

Meusel H. \& Mühlberg H. 1971-1978. Dianthus L. In: Hegi G. Illustrierte Flora von Mitteleuropa, ed. 2, vol. 3(2): 984-1037. Verlag Paul Parey, München, Berlin-Hamburg.

Meusel H., Jäger E. \& Weinert E. 1965. Vergleichende Chorologie der zentraleuropäischen Flora. I. Text 583 pp., Karten 258 pp. Gustav Fischer Verlag, Jena.

Nowak A. \& Spalek K. (ed.). 2002. Czerwona Księga Roślin Województwa Opolskiego. Rośliny naczyniowe wymarłe, zagrożone i rzadkie. 160 pp. Seria Wydawnicza "Przyroda Opolska", Opole.

Olaczek R. (ed.). 2011. Czerwona Księga Roślin Województwa Łódzkiego. Zagrożone rośliny naczyniowe. Zagrożone zbiorowiska roślinne. 296 pp. Ogród Botaniczny w Łodzi, Uniwersytet Łódzki.
PięKoŚ-Mirkowa H. 1990. Ekologia, zagrożenie i ochrona rzadkich gatunków roślin górskich. Studia Naturae A, 33: 1-199. PWN, Warszawa-Kraków.

Rothmaler W., Jäger E. J. \& Werner K. 2005. Exkursionsflora von Deutschland. Band 4, Gefäßpflanzen: Kritischer Band. 980 pp. Spektrum Akademischer Verlag, Elsevier Gmbh, München.

Sajkiewicz R. 2003. Nowe informacje o rozmieszczeniu Dianthus gratianopolitanus Vill. w Wielkopolsce. Rocz. Nauk. Pol. Tow. Ochr. Przyr. "Salamandra" 7: 5-15.

SAJKIEwiCz R. 2005. Perspektywy zachowania Dianthus gratianopolitanus Vill. na stanowisku w okolicach Pszczewa (Pojezierze Międzychodzko-Sierakowskie). In: B. JACKOWIAK \& Z. Celka (eds.). Taksonomia, chorologia i ekologia roślin w dobie zagrożenia różnorodności biologicznej. Materiały konferencji naukowej dedykowanej Profesorowi dr. hab. Waldemarowi Żukowskiemu z okazji 70-lecia urodzin, p. 286. UAM Poznań.

Węglarski K. \& JańczyK-Węglarska J. 2000. Aktywna ochrona gatunku zagrożonego wymarciem na przykładzie Dianthus gratianopolitanus Vill. z rezerwatu "Goździk siny w Grzybnie" (woj. wielkopolskie). Bad. Fizjogr. Pol. Zach. seria B-Botanika 49: 157-172.

Wolska K. 1960. Projektowany rezerwat goździka sinego (Dianthus caesius Sm.) w nadl. Sowiniec w pow. śremskim (woj. poznańskie). Przyr. Pol. Zach. 4(14): 140-141.

ZARAN-JASZCZAK E. 1995 (mscr.). Monitoring oraz ochrona czynna ex situ Cladium mariscus (L.) Phol. i Dianthus gratianopolitanus Vill. jako zagrożonych gatunków roślin naczyniowych Wielkopolski. MA Thesis, Botanical Garden of Adam Mickiewicz University, Poznań.

ZARZYCKI K. 1984. Ekologiczne liczby wskaźnikowe roślin naczyniowych Polski. 45 pp. Inst. Botaniki PAN, Kraków.

Zarzycki K., Trzcińska-Tacik H., Różański W., Szeląg Z., WoleK J. \& KorzeniaK U. 2002. Ecological indicator values of vascular plants of Poland. In: Z. MireK (ed.). Biodiversity of Poland 2, 183 pp. W. Szafer Institute of Botany, Polish Academy of Sciences, Kraków.

ŻóŁkoś K., Afranowicz R., Bloch-OrŁowska J. \& MinasieWICZ J. 2010. Problems of metaplantation of protected species - a case study of sea holly (Eryngium maritimum L.) and dark red helleborine (Epipactis atrorubens (Hoffm.) Besser). Baltic Coastal Zone Journal of Ecology and Protection of the Coastline 14: 17-23. 